\title{
Turner syndrome presented with tall stature due to overdosage of the SHOX gene
}

\author{
Go Hun Seo, MD', \\ Eungu Kang, MD', \\ Ja Hyang Cho, MD', \\ Beom Hee Lee, MD', \\ Jin-Ho Choi, MD', \\ Gu-Hwan Kim, PhD², \\ Eul-Ju Seo, MD, PhD', \\ Han-Wook Yoo, MD, PhD ${ }^{1,2}$ \\ ${ }^{1}$ Department of Pediatrics, ${ }^{2}$ Medical \\ Genetics Center, Asan Medical \\ Center Children's Hospital, University \\ of Ulsan College of Medicine, Seoul, \\ Korea
}

Turner syndrome is one of the most common chromosomal disorders. It is caused by numerical or structural abnormalities of the $\mathrm{X}$ chromosome and results in short stature and gonadal dysgenesis. The short stature arises from haploinsufficiency of the SHOX gene, whereas overdosage contributes to tall stature. This report describes the first Korean case of Turner syndrome with tall stature caused by SHOX overdosage. The patient presented with primary amenorrhea and hypergonadotropic hypogonadism at the age of 17 years. Estrogen replacement therapy was initiated at that time. She displayed tall stature from childhood, with normal growth velocity, and reached a final height of $190 \mathrm{~cm}$ (standard deviation score, 4.3 ) at the age of 30 years. Her karyotype was $46, X$, psu idic(X)(q21.2), representing partial monosomy of $\mathrm{Xq}$ and partial trisomy of $\mathrm{Xp}$. Analysis by multiplex ligationdependent probe amplification detected a duplication at Xp22.3-Xp22.2, encompassing the PPP2R3 gene near the 5 '-end of the SHOX gene through the FANCD gene at Xp22.2.

\section{Keywords: Turner syndrome, SHOX protein, Gonadal dysgenesis}

\section{Introduction}

Turner syndrome (TS) is one of the most common chromosomal disorders. It is caused by the loss of an X chromosome or the presence of a structurally abnormal X chromosome and has an estimated incidence of one in 2,500 girls born live ${ }^{1)}$. The cardinal features, which occur in more than $90 \%$ of TS cases, are short stature and gonadal dysgenesis ${ }^{2}$. The patients with TS also have multisystemic complications such as congenital heart defects, skeletal anomalies, hearing impairment, ophthalmologic abnormalities, and renal structural anomalies ${ }^{2)}$. In addition, TS patients manifest dysmorphic features such as high arched palate, micrognathia, low-set ears, epicanthal folds, lymphedema of hands and feet, and webbed neck ${ }^{2}$.

One candidate gene for short stature is located at the pseudoautosomal region 1 (PAR1) in the short arm of the X chromosome ${ }^{3)}$. This gene was discovered on the distal part of PAR1, and was designated the short stature homeobox-containing (SHOX) gene or pseudoautosomal homeobox-containing osteogenic $(P H O G)$ gene ${ }^{4,5)}$. The SHOX gene is expressed in limbs, pharyngeal arches, osteogenic cells, and bone marrow fibroblasts, and is involved in skeletal growth and development ${ }^{6,7)}$. The loss of the SHOX gene therefore leads to short stature and various skeletal abnormalities, such as short metacarpals, high-arched palate, cubitus valgus, Madelung deformity, and mesomelia ${ }^{6,7)}$. The SHOX gene is expressed on both the inactive $\mathrm{X}$ chromosome and the active $\mathrm{X}$ or $\mathrm{Y}$ chromosome, thereby escaping from $\mathrm{X}$ chromosome inactivation $^{4)}$. According to the altered SHOX dosage, haploinsufficiency causes short stature, while overdosage contributes to tall stature.

Several TS patients with tall stature caused by SHOX overdosage have been reported worldwide $^{8-11)}$. Recently, we experienced the first Korean patient with tall stature caused by SHOX overdosage.
Received: 2 June, 2015

Revised: 15 June, 2015

Address for correspondence: Han-Wook Yoo, MD, PhD

Department of Pediatrics, Asan Medical Center Children's Hospital, University of Ulsan College of Medicine, 88 Olympic-ro 43-gil, Songpa-gu, Seoul 138-736, Korea Tel: +82-2-3010-3374 Fax: +82-2-473-3725

E-mail: hwyoo@amc.seoul.kr 


\section{Case report}

The patient was born at term, without any perinatal problems, to nonconsanguineous Korean parents. Her prenatal evaluation was unremarkable. She did not experience any particular problem until her late teens.

At 17 years of age, she was brought to medical attention because of primary amenorrhea and the absence of secondary sexual characteristics. She was $183.5 \mathrm{~cm}$ (standard deviation score [SDS], 3.3) tall and weighed $77.4 \mathrm{~kg}$ (SDS, 2.0). Her body mass index (BMI) was $23 \mathrm{~kg} / \mathrm{m}^{2}$ (SDS, 0.7). Her midparental height was $168.5 \mathrm{~cm}$. Her serum luteinizing hormone (LH) and follicle-stimulating hormone (FSH) levels were $19.9 \mathrm{mIU} / \mathrm{mL}$ and $32.5 \mathrm{mIU} / \mathrm{mL}$, respectively. Her serum estradiol was $<10 \mathrm{pg} /$ $\mathrm{mL}$. Transrectal ultrasonography (US) showed a normal-sized uterus and adnexa. Her abdominal US and echocardiogram were normal. Hormone replacement therapy was initiated with $0.625 \mathrm{mg}$ of conjugated estrogen on day $1-23$ and $10 \mathrm{mg}$ of medroxyprogesterone acetate on day10-23 every month. There was no menstruation after 6 months of medication, and the medications were replaced with $2.06 \mathrm{mg}$ of estradiol hemihydrate for 14 days and the addition of dydrogesterone $(10 \mathrm{mg}$ ) for the next 14 days every month. At 18 years of age, the follow-up transrectal US showed no specific findings. She manifested pubertal development (breast and pubic hair, Tanner stage 3). However, she still did not menstruate.

She was referred to a pediatric endocrinology clinic at the age of 29 years during hormone replacement therapy. She was 190 $\mathrm{cm}$ (SDS, 4.3) tall and weighed $101 \mathrm{~kg}$ (SDS, 3.3), with a BMI of $28.1 \mathrm{~kg} / \mathrm{m}^{2}$ (SDS, 1.6). Her serum LH, FSH, and estradiol levels were $9.0 \mathrm{mIU} / \mathrm{mL}, 17.4 \mathrm{mIU} / \mathrm{mL}$, and $18.1 \mathrm{pg} / \mathrm{mL}$, respectively. Her serum triglyceride, total cholesterol, and high-density lipoprotein-cholesterol levels were $234 \mathrm{mg} / \mathrm{dL}, 138 \mathrm{mg} / \mathrm{dL}$, and $34 \mathrm{mg} / \mathrm{dL}$, respectively. Her blood pressure was normal. An x-ray of her left hand demonstrated complete epiphyseal fusion of the radius and ulna. Karyotype analysis revealed a nonmosaic pseudoisodicentric Xp chromosome, i.e., 46,X, psu $\operatorname{idic}(X)(q 21.2)$ (Fig. 1). Multiplex ligation-dependent probe amplification (MLPA) analysis identified duplication of the Xp22.3-Xp22.2 region, encompassing the SHOX gene (Fig. 2).

She did not menstruate until she was 30 years old and still presented with breast and pubic hair at Tanner stage 3. Her weight had increased to $102.5 \mathrm{~kg}$ (SDS, 3.4) with a BMI of 28.4 $\mathrm{kg} / \mathrm{m} 2$ (SDS, 1.7).

\section{Discussion}

This report describes the first Korean case of a TS patient who presented with tall stature due to SHOX overdosage. Approximately $45 \%$ of patients with TS have a 45, X karyotype, $10 \%$ have an isochromosome $\mathrm{Xq}$, and the remaining patients have mosaicism or structural abnormalities of the $\mathrm{X}$ chromosome ${ }^{1)}$. The present case had a nonmosaic 46, X, psu $\operatorname{idic}(\mathrm{Xq} 21.2)$ and presented with tall stature, surpassing the midparental height without other typical features of TS, except gonadal dysgenesis. The isochromosome $\mathrm{X}$ has a breakpoint at

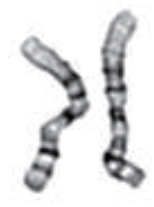

1

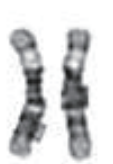

6

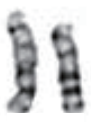

13

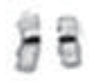

19

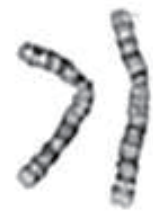

2

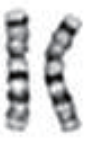

7

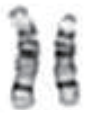

14

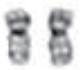

20

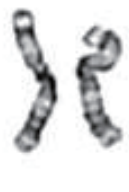

3

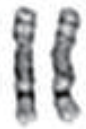

8

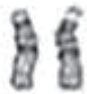

15

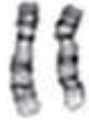

9
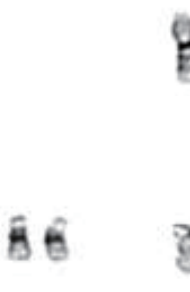

21

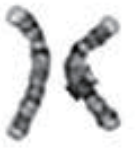

4

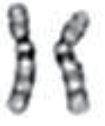

10

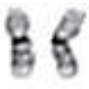

16

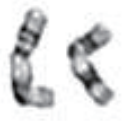

11

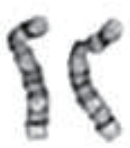

5
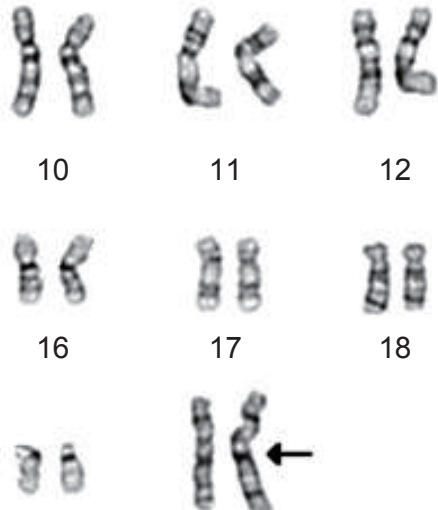

22

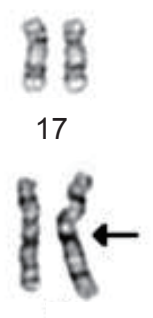

$\mathrm{X}$

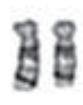

18

Fig. 1. Chromosome analysis revealed 46,X, psu idic(Xq21.2). The arrow indicates a breakpoint at Xq21.2, indicating the deletion of the Xq21.2-Xqter and duplication of the Xpter-Xq21.2. 

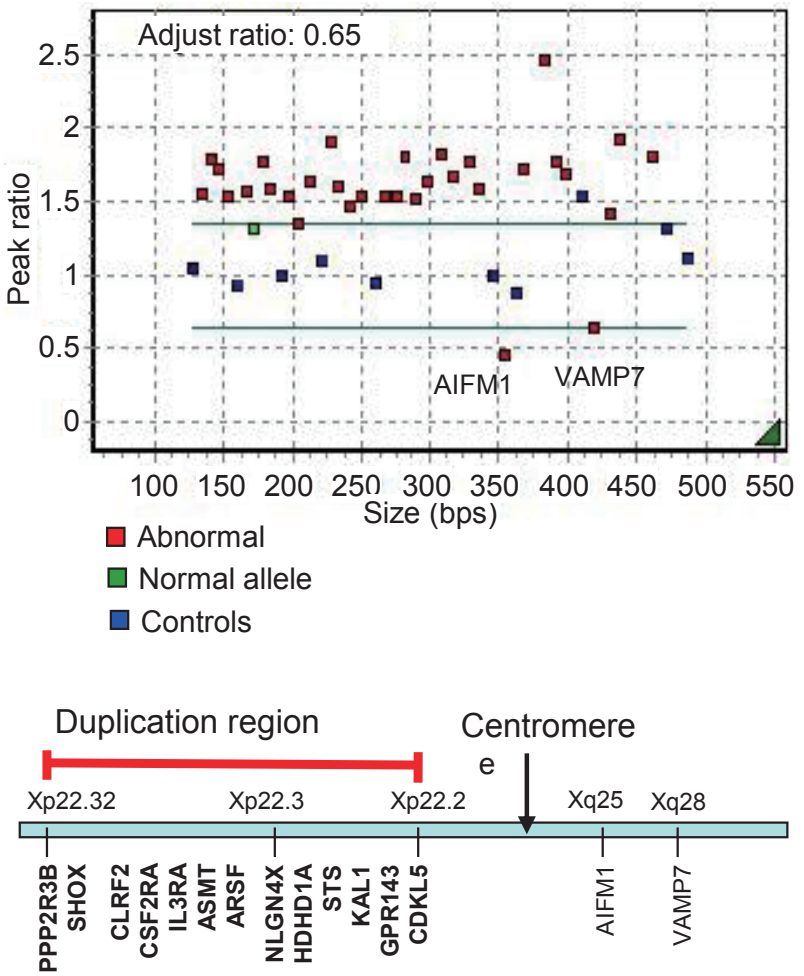

Fig. 2. Multiple ligation-dependent probe amplification (MLPA) analysis was performed using a SALSA MLPA P018-D1 Reference Kit (MRC Holland, Amsterdam, the Netherlands) according to the manufacturer's instructions. Amplified products were separated by electrophoresis and analyzed using an ABI3130 Genetic Analyzer (Applied Biosystems, Foster City, CA, USA). The peak height of each probe was analyzed using Gene Mapper Software (Applied Biosystems). Duplication was detected at the Xp22.3-Xp22.2 region, including the SHOX gene.

Xq21.2 and shows partial monosomy of Xq and partial trisomy of Xp. This implies a duplication of the terminal portion of $\mathrm{Xp}$, including the SHOX gene. MLPA analysis confirmed the duplication from the PPP2R3 gene at the Xp22.3 to the FANCD gene at the Xp22.2 region (Fig. 2).

Several studies have demonstrated a correlation between SHOX overdosage and tall stature, as well as hypergonadotropic hypogonadism ${ }^{9,10)}$. SHOX overdosage and gonadal dysgenesis contribute to sustained growth, with constant height velocity from infancy to adolescence ${ }^{9,10)}$. The SHOX gene accelerates linear growth and inhibits fusion of the epiphyseal plate ${ }^{12,13)}$, resulting in a marked increase in leg length and subsequent change in body proportion ${ }^{10}$. Although data are limited regarding the body ratio of the present case, a much longer lower than upper segment might be expected.

This patient continued to grow after 18 years of age, despite estrogen replacement therapy lasting 10 years, suggesting that SHOX overdosage surpasses the skeletal maturing effect of estrogen ${ }^{9)}$. However, other deleted genes on Xq or duplicated genes on Xp could have contributed to the tall stature of our patient.

A TS patient with mosaicism that includes a $45, X$ cell lineage can show a normal height until the early teens and can be taller than the target height until the late teens. This finding suggests that cell lineages determining height may be $46, \mathrm{X}$,idic $(\mathrm{X})$ or $46, X, \operatorname{der}(\mathrm{X})$, rather than the $45, \mathrm{X}$ cell lineage ${ }^{9-11)}$. With this in mind, the present case showed tall stature until her late teens.

In summary, this report describes a TS patient with tall stature caused by a SHOX gene overdosage and estrogen deficiency, although tall stature could rarely be associated with TS in case of structurally abnormal X chromosome containing an extra Xp.

\section{Conflict of interest}

No potential conflict of interest relevant to this article was reported.

\section{Acknowledgments}

This study was supported by a grant from the National Research Foundation of Korea, funded by the Ministry of Education, Science, and Technology (NRF-2011-0019674).

\section{References}

1. Stochholm K, Juul S, Juel K, Naeraa RW, Gravholt CH. Prevalence, incidence, diagnostic delay, and mortality in Turner syndrome. J Clin Endocrinol Metab 2006;91:3897902.

2. Sybert VP, McCauley E. Turner's syndrome. N Engl J Med 2004;351:1227-38.

3. Ogata T, Matsuo N. Sex chromosome aberrations and stature: deduction of the principal factors involved in the determination of adult height. Hum Genet 1993;91:551-62.

4. Rao E, Weiss B, Fukami M, Rump A, Niesler B, Mertz A, et al. Pseudoautosomal deletions encompassing a novel homeobox gene cause growth failure in idiopathic short stature and Turner syndrome. Nat Genet 1997;16:54-63.

5. Ellison JW, Wardak Z, Young MF, Gehron Robey P, LaigWebster M, Chiong W. PHOG, a candidate gene for involvement in the short stature of Turner syndrome. Hum Mol Genet 1997;6:1341-7.

6. Clement-Jones M, Schiller S, Rao E, Blaschke RJ, Zuniga A, Zeller R, et al. The short stature homeobox gene SHOX is involved in skeletal abnormalities in Turner syndrome. Hum Mol Genet 2000;9:695-702.

7. Oliveira CS, Alves C. The role of the SHOX gene in the pathophysiology of Turner syndrome. Endocrinol Nutr 2011;58:433-42.

8. Nakamura Y, Suehiro Y, Sugino N, Sasaki K, Kato H. A case of 46,X,der $(X)($ pter-->q21::p21-->pter) with gonadal dysgenesis, tall stature, and endometriosis. Fertil Steril 2001;75:1224-5.

9. Ogata T, Kosho T, Wakui K, Fukushima Y, Yoshimoto M, 
Miharu N. Short stature homeobox-containing gene duplication on the $\operatorname{der}(\mathrm{X})$ chromosome in a female with $45, \mathrm{X} / 46, \mathrm{X}, \operatorname{der}(\mathrm{X})$, gonadal dysgenesis, and tall stature. J Clin Endocrinol Metab 2000;85:2927-30.

10. Ogata T, Inokuchi M, Ogawa M. Growth pattern and body proportion in a female with short stature homeobox-containing gene overdosage and gonadal estrogen deficiency. Eur J Endocrinol 2002;147:249-54.

11. Nishi MY, Correa RV, Costa EM, Billerbeck AE, Cruzes AL, Domenice S, et al. Tall stature and poor breast development after estrogen replacement in a hypergonadotrophic hypogonadic patient with a 45,X/46,X,der(X) karyotype with SHOX gene overdosage. Arq Bras Endocrinol Metabol 2008;52:1282-7.

12. Kosho T, Muroya K, Nagai T, Fujimoto M, Yokoya S, Sakamoto H, et al. Skeletal features and growth patterns in 14 patients with haploinsufficiency of SHOX: implications for the development of Turner syndrome. J Clin Endocrinol Metab 1999;84:4613-21.

13. Ogata T, Matsuo N, Nishimura G. SHOX haploinsufficiency and overdosage: impact of gonadal function status. J Med Genet 2001;38:1-6. 